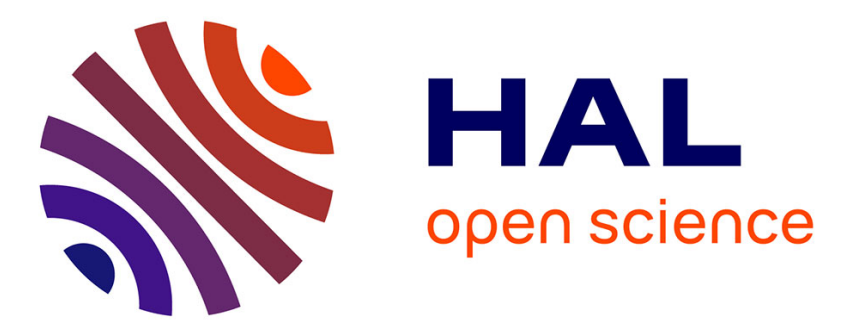

\title{
Impact of spray-drying conditions on flow properties of skim dromedary and cow's milk powders using the FT4 powder rheometer
}

Imène Felfoul, Jennifer Burgain, Carole Perroud, Claire Gaiani, Joël Scher, Hamadi Attia, Jérémy Petit

\section{To cite this version:}

Imène Felfoul, Jennifer Burgain, Carole Perroud, Claire Gaiani, Joël Scher, et al.. Impact of spraydrying conditions on flow properties of skim dromedary and cow's milk powders using the FT4 powder rheometer. Journal of Food Processing and Preservation, 2021, 45 (6), 10.1111/jfpp.15566 . hal03330387

\section{HAL Id: hal-03330387 \\ https://hal.univ-lorraine.fr/hal-03330387}

Submitted on 31 Aug 2021

HAL is a multi-disciplinary open access archive for the deposit and dissemination of scientific research documents, whether they are published or not. The documents may come from teaching and research institutions in France or abroad, or from public or private research centers.
L'archive ouverte pluridisciplinaire HAL, est destinée au dépôt et à la diffusion de documents scientifiques de niveau recherche, publiés ou non, émanant des établissements d'enseignement et de recherche français ou étrangers, des laboratoires publics ou privés. 


\section{Impact of spray-drying conditions on flow properties of skim dromedary and cow's milk powders using the FT4 powder rheometer}

Imène Felfoul, Jennifer Burgain, Carole Perroud, Claire Gaiani, Joël Scher, Hamadi Attia, Jérémy Petit

\section{To cite this version:}

Imène Felfoul, Jennifer Burgain, Carole Perroud, Claire Gaiani, Joël Scher, et al.. Impact of spraydrying conditions on flow properties of skim dromedary and cow's milk powders using the FT4 powder rheometer. Journal of Food Processing and Preservation, Wiley, 2021, 45 (6), 10.1111/jfpp.15566 . hal-03330387

\section{HAL Id: hal-03330387 \\ https://hal.univ-lorraine.fr/hal-03330387}

Submitted on 31 Aug 2021

HAL is a multi-disciplinary open access archive for the deposit and dissemination of scientific research documents, whether they are published or not. The documents may come from teaching and research institutions in France or abroad, or from public or private research centers.
L'archive ouverte pluridisciplinaire HAL, est destinée au dépôt et à la diffusion de documents scientifiques de niveau recherche, publiés ou non, émanant des établissements d'enseignement et de recherche français ou étrangers, des laboratoires publics ou privés. 


\section{Journal of \\ Food Processing and Preservation}

\section{Impact of spray-drying conditions on flow properties of skim dromedary and cow's milk powders using the FT4 powder rheometer}

\begin{tabular}{|r|l|}
\hline Journal: & Journal of Food Processing and Preservation \\
\hline Manuscript ID & JFPP-09-20-2207.R1 \\
\hline Manuscript Type: & Original Article \\
\hline Date Submitted by the & n/a \\
\hline Complete List of Authors: & $\begin{array}{l}\text { Felfoul, Imène; National Engineering School of Sfax } \\
\text { Burgain, Jennifer ; Universite de Lorraine, Physicochimie et génie des } \\
\text { procédés alimentaire } \\
\text { Perroud, Carole; Universite de Lorraine, LIBio } \\
\text { GAIANI, Claire; Université de Lorraine, LIBio (Laboratoire d'Ingénierie } \\
\text { des biomolécules } \\
\text { Scher, Joël; Universite de Lorraine, LIBio } \\
\text { attia, hamadi; Ecole Nationale d'Ingenieurs de Sfax } \\
\text { Petit, Jeremy; University of Lorraine, Biomolecular Research }\end{array}$ \\
\hline Keywords: & $\begin{array}{l}\text { spray-drying, flowability, dromedary milk powder, basic flowability } \\
\text { energy, specific energy }\end{array}$ \\
\hline
\end{tabular}

\section{SCHOLARONE ${ }^{\text {Th }}$ Manuscripts}


1 Impact of spray-drying conditions on flow properties of skim dromedary 2 and cow's milk powders using the FT4 powder rheometer

3

4 Imène FELFOUL ${ }^{a^{*}}$, Jennifer BURGAIN ${ }^{b}$, Carole PERROUD ${ }^{b}$, Claire GAIANI ${ }^{b}$, 5 Joël SCHER ${ }^{\mathrm{b}}$, Hamadi ATTIA ${ }^{\mathrm{a}}$, Jérémy PETIT ${ }^{\mathrm{b}}$

6 *Corresponding author. Tel.: +216 74675761

7 E-mail address: imenef@gmail.com / imen.falfoul@isbs.usf.tn

8

9 a Université de Sfax, Laboratoire Analyses, Valorisation et Sécurité des Aliments (LAVASA), 10 Ecole Nationale d'Ingénieurs de Sfax, Route de Soukra, 3038 Sfax, Tunisia

11 b Université de Lorraine, LIBio (Laboratoire d'Ingénierie des Biomolécules), F-54000 Nancy, 12 France. 


\section{ABSTRACT}

14 Two sets of spray-drying conditions were applied on skim dromedary and cow's milks

15 to determine the effect of air outlet temperature $\left(75\right.$ and $\left.85^{\circ} \mathrm{C}\right)$ and milk type on proximate 16 composition, particle size distribution, and flow properties of spray-dried powders. The particle

17 size distribution was more influenced by the chemical composition than the spray-drying 18 conditions. The air outlet temperature impacted on dromedary milk powder flowability, as the 19 basic flowability energy was significantly increased from 620 to $1018 \mathrm{~mJ}$ when the outlet air 20 temperature was increased from 75 to $85^{\circ} \mathrm{C}$, respectively. Specific energy, associated with the 21 flow performance of a powder in a low stress environment, were significantly higher for 22 dromedary milk powder at the higher air outlet temperature. However, spray-drying conditions 23 had no significant effect on specific energy values of cow's milk powder. Dromedary milk 24 powders had better flow behavior than cow's milk powders. Shear tests confirmed that powders 25 spray-dried at $75^{\circ} \mathrm{C}$ had better flowability than powders spray-dried at $85^{\circ} \mathrm{C}$.

\section{NOVELTY IMPACT STATEMENT}

27 Powdering is particularly interesting for dromedary milk industrialization, as a way to 28 overcome problems related to production seasonality and commercialization in low production 29 regions. Using a lower air outlet temperature $\left(75^{\circ} \mathrm{C}\right)$ led to better flowability and lower 30 compressibility. Shear tests showed that cow's milk powders were more cohesive than 31 dromedary milk powders.

32 Keywords: spray drying; flowability; dromedary milk powder; basic flowability energy; 33 specific energy; shear test. 
35 Milk transformation into a powdered product by means of a drying process is widely used in 36 the dairy industry (Hammes, Englert, Noreña, \& Cardozo, 2015). Milk powder can be preserved

37 for longer times and its production reduces the cost of certain operations, such as packing, 38 storage, and transportation (Kitamura, Itoh, \& Echizen, 2009). Powdering processes allow the

39 almost complete preservation of nutrients (Gaiani et al., 2010). In the case of dromedary milk, 40 powdering is particularly interesting for product industrialization, as a way to overcome 41 problems related to production seasonality and commercialization in low production regions.

42 Indeed, it is possible to store powdered milk in areas and periods of high production, in order 43 to fulfill the demand where and when dromedary milk is not produced enough.

44 The drying step determines the quality of resulting powder; the choice of drying method 45 and conditions is dictated by the nature of the material to be dried, the desired powder 46 functionalities, and economic factors (Jinapong, Suphantharika, \& Jamnong, 2008; Esquivel \& 47 Jiménez, 2012). Spray-drying is the most commonly used technique for industrial production 48 of milk powder, because it generates a product of good quality with better organoleptic and 49 nutritional features than drum-drying, while being faster and cheaper than freeze-drying 50 (Ceballos, Giraldo, \& Orrego, 2012; Reddy et al., 2014).

51 To the best of our knowledge, only a few studies in the literature have been dedicated

52 to spray-dried dromedary milk powder and they were restricted to the determination of the 53 influence of the drying process on the nutritional, physicochemical, and organoleptic properties 54 of powders, as well as their storage stability. For instance, Sulieman, Elamin, Elkhalifa, and 55 Laleye (2014) reported that the physicochemical and functional properties of spray-dried 56 dromedary milk powder (water activity, powder color, solubility, flowability) were greatly 57 affected by the velocity difference (both in terms of intensity and direction) between feed and 58 air and they described thermal properties of freeze-dried whole and skim dromedary milks on 
59 the basis of glass transition and melting temperatures of their major components (lipids, caseins,

60 whey proteins, and lactose). Al-Juboori, Mohammed, Rashid, Kurian, and El Refaey (2013)

61 revealed the dependence of physicochemical properties (water activity, glass transition

62 temperature, bulk density, free fat content, and whey protein nitrogen index) of spray-dried

63 dromedary milk powders on fat content of feeding concentrate and spray-drying temperature.

64 Zouari et al. (2019) investigated the effect of spray-drying parameters on the production of

65 dromedary milk powder (water activity, glass transition temperature, bulk density, and free fat

66 content). Ho et al. (2019) evaluated the stability of spray-dried dromedary milk powder and

67 denoted modifications of several physicochemical properties upon accelerated aging. To the

68 authors' knowledge, there has been no study on the effect of spray-drying conditions on flow

69 properties of dromedary skim milk powder. Good powder flow properties enable high

70 production efficiency as well as improved powder product quality (Fitzpatrick et al., 2007;

71 Krantz, Zhang, \& Zhu, 2009). Indeed, in manufacturing processes involving powders as

72 ingredients or products, many unit operations, such as transfer from a silo or hopper,

73 fluidization, pneumatic transportation, and mixing, require good flow properties of handled

74 powders. Insufficient powder flow may be detrimental for the monitoring of some unit

75 operations, resulting in poor quality of the end product (for instance, cohesive powders

76 generally are more susceptible to agglomerate, resulting in particle sizes higher than

77 specifications) and/or modifications of process conditions (for example, cohesive powders are

78 more hardly fluidized, thus necessitating the use of higher air velocities for fluidization

79 purposes, leading to more intense interparticular and particle-wall shocks that are likely to break

80 particles and affect their size and shape). Moreover, good flow is required in powder mixing

81 processes to ensure even distribution: it is more difficult to form a homogeneous mixture with

82 cohesive powders or agglomerates than with powders composed of non-cohesive individual

83 particles (Krantz, Zhang, \& Zhu, 2009). The characterization of powder flowability can be 
achieved with the FT4 powder rheometer (Freeman Technology). Flow properties of various

85 food products have been determined using the FT4 powder rheometer: for instance, powdered

86 dairy products (Lapčík et al., 2015), fermented milk-cereal mixtures (Salameh et al., 2016), and

87 plantain-based formulated powders (Gnagne, Petit, Gaiani, Scher, \& Amani, 2017).

88 Two sets of spray-drying process conditions were applied on skim dromedary and cow's

89 milks in order to evaluate the impact of drying air temperature and milk type on the flow

90 properties of resulting milk powders. The proximal composition and the particle size

91 distribution were also evaluated in order to better understand the links between physicochemical

92 properties and flowability of studied powders.

\section{2. MATERIAL AND METHODS}

\subsection{Dromedary and cow's milk samples}

Dromedary (Camelus dromedarius) milk was obtained from a local breeding located in

96 the south of Tunisia (Gabès governorate, Tunisia). Dromedary milk was constituted of pooled

97 milk samples assembled from twenty different healthy dromedaries (Camelus dromedarius),

98 whose lactation time ranged between 2 and 8 months. Cow's milk, collected from healthy

99 Holstein cows, was provided by a farm located in the north-east of France (experimental domain 100 of La Bouzule, ENSAIA, Laneuvelotte, France). Both milks were collected in sterile milking 101 cans, in which sodium azide was promptly added up to $0.02 \%(\mathrm{w} / \mathrm{w})$ to ensure microbiological 102 stability; after that, they were conveyed into a cool box filled with ice to the laboratory and then 103 stored at $4{ }^{\circ} \mathrm{C}$ until skimming. Both milks were skimmed at $3000 \times g$ during 20 min at $4{ }^{\circ} \mathrm{C}$ 104 (Gyrozen 1580MGR, Multi-purpose Centrifuge, Daejeon, Korea). Then, both skim milks were 105 stored at $-20{ }^{\circ} \mathrm{C}$ until use for spray-drying.

$106 \quad$ 2.2. Spray-drying of skim dromedary and cow's milks

107 Skim dromedary and cow's milks were sieved at $50 \mu \mathrm{m}$ mesh size (test sieve, Mesh S108 Steel, $200 \mathrm{~mm}$ diameter, $50 \mathrm{~mm}$ height, Retsch $\mathrm{GmbH}$, Germany) in order to remove the 
109 potential residual coalesced fat globules. Spray-drying of skim milks was performed in a 110 MicraSpray MS 150 simple effect pilot plant spray-dryer (Anhydro, Soeborg, Denmark) 111 equipped with a bi-fluid nozzle (Fluid Cap 60100 + Air Cap 120, Spraying System, Wheaton, 112 Illinois, USA). Aspiration rate was set at $70 \%$ for all performed assays. In the drying chamber, 113 the drying air cocurrently flowed with milk droplets sprayed from the bi-fluid nozzle. The 114 spray-dryer was fed at $27^{\circ} \mathrm{C}$ with a FAST Load peristaltic pump (VWR, Leuven, Belgium, 48 $115 \mathrm{~mm}$ internal pipe diameter). Dromedary and cow's milks were first skimmed, then stored at $11620{ }^{\circ} \mathrm{C}$. For spray-drying experiments, both skim milks were thawed out at $4{ }^{\circ} \mathrm{C}$ overnight. Last, 117 both milks were prewarmed at $27^{\circ} \mathrm{C}$ in a water bath to improve spray-drying production 118 efficiency (mainly, pumping of the concentrate through the bi-fluid nozzle).

119 The spray-drying conditions such as air inlet and outlet temperatures as well as drying 120 air flow rate suitable for the production of skim milk powder were selected not only based on 121 literature (Schuck, Jeantet, \& Dolivet, 2012) and but also after preliminary experimentations in 122 order to obtain skim milk powders suitable for storage, i.e. having a moisture content not 123 exceeding $5 \%$ (w/w) (Schuck, Jeantet, \& Dolivet, 2012; Felfoul et al., 2020). Two assays 124 differing in spray-drying conditions were carried out with a view to evaluate the influence of 125 air outlet temperature (Table 1). It is worth noting that $\mathrm{C} 1$ and $\mathrm{C} 2$ spray-drying conditions 126 differed in outlet air temperature (circa 74.5 and $84.5^{\circ} \mathrm{C}$, respectively) and feed flow-rate (about 12775 and $67 \mathrm{~mL} \cdot \mathrm{min}^{-1}$, respectively).

128 With this experimental setup, the process parameter having the most influence on 129 powder physicochemical and functional properties should be the air outlet temperature rather 130 than the feed flow-rate. The feed flow rate was a little higher in C1 conditions (Table 1), 131 meaning that liquid velocity at the nozzle outlet was a little higher and resulting in slightly 132 lower air-liquid velocity difference at the nozzle outlet; this should result in slightly larger 133 droplets (Petit et al., 2015; Mandato et al., 2012) and thus slightly larger spray-dried particles 
in $\mathrm{C} 1$ conditions. However, the effect of feed flow-rate was likely negligible compared to the one of drying air temperature, because the air-liquid velocity difference at the nozzle outlet was

136 not markedly affected by changing the feed flow-rate, as the air velocity is much greater than

137 the liquid velocity at the outlet of a bi-fluid nozzle (Petit et al., 2015; Mandato et al., 2012).

138 The powders were then collected, immediately packed in sealed polyethylene 139 terephthalate bags, and stored at $10^{\circ} \mathrm{C}$ until analysis. All analyses were carried out within a 140 week after powder production. Spray-drying yield was calculated as the ratio between the dry 141 mass of powder and the dry mass of feed skim milk.

\subsection{Proximate composition of skim dromedary and cow's milks and powders}

Moisture, protein, and ash contents of skim milks and powders were determined

144 according to the AOAC standard methods (A.O.A.C., 2016). Moisture content was determined

145 by mass loss after drying $10 \mathrm{~mL}$ milk or $3 \mathrm{~g}$ powder in an air oven at $105^{\circ} \mathrm{C}$ for $7 \mathrm{~h}$. Ash content 146 was obtained by mass loss after incinerating $10 \mathrm{~mL}$ milk sample or $3 \mathrm{~g}$ powder in a furnace at $147550^{\circ} \mathrm{C}$ during $6 \mathrm{~h}$. Proteic nitrogen content was determined by the Kjeldahl method (Vapodest, 148 Gerhardt $\mathrm{GmbH}$ \& Co. KG, Königswinter, Germany) and protein content was deduced from 149 nitrogen content using a conversion factor of 6.38 (Felfoul et al. 2020).

150 Fat content of milks (using $11 \mathrm{~mL}$ milk sample) was determined according to the Gerber 151 acid-butyrometric method (ISO 11870:2009) using $10 \mathrm{~mL}$ of sulfuric acid in order to dissolve 152 milk proteins. The fat separation was carried out by centrifugation in a butyrometer at 1100 $153 \mathrm{tr} / \mathrm{min}$ for $5 \mathrm{~min}$ at $65^{\circ} \mathrm{C}$ in the presence of $1 \mathrm{~mL}$ of isoamyl alcohol. Fat content of powders 154 was determined using the Folch method (1957) by performing solvent extraction of $2 \mathrm{~g}$ powder 155 using a mix of 2:1 (v/v) chloroform/methanol.

156 Carbohydrates content was deduced by difference with other components assuming that 157 vitamins were weakly represented (Felfoul et al., 2020).

158 


\subsection{Particle size distribution}

160

Particle size distributions of powders were determined with a laser granulometer

161 (Mastersizer 2000 Malvern Instruments, UK), equipped with $\mathrm{He}-\mathrm{Ne}$ laser (632.8 nm

162 wavelength), using the Aero S module for dry dispersion in the following conditions: 2 bar; 100

$163 \%$ air pressure; $100 \%$ feed rate; $3 \mathrm{~mm}$ hopper gap. The mean diameter in volume was chosen

164 as particle size estimator. Classical granulometric parameters $\mathrm{D}_{10}, \mathrm{D}_{50}$, and $\mathrm{D}_{90}$ were recorded

$165\left(\mathrm{D}_{\mathrm{X}}\right.$ corresponds to the size for which $\mathrm{X} \%$ of the particle population has smaller size). Span

166 was calculated to evaluate the width of the particle size distribution (equation 1) (Felfoul et al.,

167 2020):

$$
\operatorname{Span}=\left(D_{90}-D_{10}\right) / D_{50} \text { Equation (1) }
$$

\subsection{Flow properties of skim dromedary and cow's milk powders}

Powder flowability was evaluated using the FT4 powder rheometer (Freeman

171 Technology, Worcestershire, UK) as previously reported in the literature (Freeman \& Fu, 2008;

172 Freeman, 2011). Stability, compressibility, and rotational shear tests were performed according

173 to the FT4 standard methods. For each test, a powder sample was poured into a FT4 cylindrical 174 vessel of $50 \mathrm{~mm}$ diameter. To ensure analytical reproducibility, FT4 analyses include a

175 preliminary step of powder conditioning, performed by a rotational and vertical moving (both

176 downwards and upwards) through the powder sample of a blade ( $5^{\circ}$ helix angle and $48.0 \mathrm{~mm}$

177 diameter) at constant tip speed of $60 \mathrm{~mm} \cdot \mathrm{s}^{-1}$. This operation removes any packing history such

178 as pre-consolidation or excess entrapped air and generates a uniform powder packing in order

179 to ensure repeatable and comparable data (Freeman, Cooke, \& Schneider, 2009). The mass of

180 skim milk powders was automatically recorded by the FT4 apparatus. The different tests carried

181 out with the FT4 powder rheometer are described hereafter.

182

183 
The stability test is designed to assess the flow energy changes upon repeated testing, it

186

187 188 18 190

191 though the powder were recorded and used to calculate the total energy input required to make

192 the powder bed flow. The basic flowability energy (BFE), corresponding to the stabilized flow 193 energy, was evaluated as the flow energy required to displace a conditioned powder sample 194 during downwards movement of the blade in the seventh test cycle (Freeman, 2007). The bulk 195 density (BD) was also obtained from the stability test and was calculated as the ratio of sample 196 mass to vessel volume $(85 \mathrm{~mL})$.

197 The specific energy (SE) is the energy needed to displace the conditioned powder bed 198 during upwards testing divided by the mass of analyzed powder sample (Equation 2). This gives 199 an indication of powder flow properties in a loosely packed and unconfined state (Mitra et al., 200 2017). SE is mostly related to intrinsic particle properties, such as cohesion, particle size and 201 shape distributions, and surface roughness.

$202 S E=$ (upwards flow energy of cycle $6+$ upwards flow energy of cycle 7$) /(2 \times$ split mass $)$ 203

206 normal stress. A powder sample was first placed in the measurement cell (i.e. two overlaid $20750 \mathrm{~mm} \times 85 \mathrm{~mL}$ glass cylinders) and submitted to three conditioning cycles performed as 208 previously described. After that, the vessel was split to remove any excess powder and the 209 dynamic blade was replaced by the $48 \mathrm{~mm}$ vented piston. Then, powder was slowly compressed 
210 by the vented piston vertically moving at $0.05 \mathrm{~mm} \cdot \mathrm{s}^{-1}$ and applying normal stresses $\sigma$ from 0.5 211 to $15 \mathrm{kPa}(0.5,1,2,4,6,8,10,12$, and $15 \mathrm{kPa})$ while measuring its volume change. After 212 reaching equilibrium at the target stress, the distance traveled by the vented piston was 213 measured and the compressibility was calculated as a percentage change in volume after 214 compression $\left(\mathrm{C}_{\mathrm{p}}\right)$. Compressibility is indicative of the level of cohesion between particles 215 (Freeman, 2007; Bian, Ambrose, \& Subramanyam, 2015). Compressed bulk density (CBD) is 216 calculated from bulk density (BD) and compressibility (Equation 3).

$$
\left.C B D=\frac{B D}{1-\frac{C_{p}}{100}} \text { (Equation } 3\right)
$$

\subsubsection{Shear cell test}

Shear cell measurements are widely used to evaluate the flowability of powders in high-

220 shear applications. The rotational shear cell of the FT4 powder rheometer consists of a vessel 221 containing the powder samples and a FT4 shear head applying both normal and rotational shear 222 stresses to the powder bed. Powder sample was first conditioned using the helical blade as 223 previously described (Quintanilla, Castellanos, \& Valverde, 2001). After the conditioning step, 224 powder sample was slowly subjected for $60 \mathrm{~s}$ to a normal stress of $9 \mathrm{kPa}$ carried out with a 225 vented piston vertically moving at a maximum speed of $0.08 \mathrm{~mm} \cdot \mathrm{s}^{-1}$. Then, the vessel 226 containing the powder sample was split, the vented piston was changed for the shear cell head, 227 and the powder sample was recompressed at $9 \mathrm{kPa}$ to remove any disturbances caused by the 228 split and ensure that the powder bed surface was properly consolidated. The preconsolidated 229 powder sample was then submitted to a preshearing stage (60 s at $9 \mathrm{kPa}$ normal stress) carried 230 out with the rotational shear cell accessory (48 $\mathrm{mm}$ diameter), to achieve a critically 231 consolidated state. The normal stress was then reduced lowered and the incipient shear stress 232 necessary to cause powder bed failure and initiate flow was measured. The preshear/shear 233 sequence was repeated five times at decreasing normal stresses $\sigma$ from 7 to $3 \mathrm{kPa}$ by $1 \mathrm{kPa}$ steps 
234 at $18^{\circ} \cdot \mathrm{min}^{-1}$ rotational speed. The curve representing the evolution of incipient shear stress with

235 applied normal stress is thus the so-called yield locus (Gnagne, Petit, Gaiani, Scher, Amani,

236 2017). Shear cell parameters, major principal stress (MPS), unconfined yield stress (UYS),

237 cohesion, and flow function (FF), were then determined with the FT4 software by the Mohr

238 circle approach using following equations 4-6 (ASTM, 2004, 2005).

239

$$
M P S=\frac{\left(\sigma_{x}+\sigma_{y}\right)}{2}+\sqrt{\left(\frac{\sigma_{x}-\sigma_{y}}{2}\right)^{2}+\tau_{x y}^{2}} \quad \text { (Equation 4) }
$$

240 Where:

$241 \tau_{x y}$ : incipient shear stress $(\mathrm{Pa}), \sigma_{\mathrm{x}}$ : stress at horizontal axis $(\mathrm{Pa}), \sigma_{\mathrm{y}}$ : stress at vertical axis $(\mathrm{Pa})$

242

$$
U Y S=P / A(\text { Equation } 5)
$$

243 Where P: axial load at failure $(\mathrm{N})$,

$244 A=\frac{A_{0}}{1-\varepsilon}=$ corrected area $\left(\mathrm{m}^{2}\right)$

245 With: $\mathrm{A}_{0}$ is the initial horizontal area of the powder bed $\left(\mathrm{m}^{2}\right)$ and $\varepsilon$ designates the axial strain 246 of powder sample $\left(\mathrm{s}^{-1}\right)$.

247 The cohesion was evaluated as the intercept of the linear regression of the yield locus curve.

248 The flow factor (FF) is the most commonly used parameter for the description of powder

249 flowability (Bian, Ambrose, \& Subramanyam, 2015). (Equation 6):

250

$$
F F=\frac{M P S}{U Y S}(\text { Equation 6) }
$$

251 The higher the flow factor, the better the powder flows. Powders were classified by Jenike 252 (1980) according to FF values as follows:

$253-\mathrm{FF}<1$ : not flowing,

$254-1<\mathrm{FF}<2$ : very cohesive,

$255 \quad-\quad 2<\mathrm{FF}<4$ : cohesive,

$256 \quad-\quad 4<\mathrm{FF}<10$ : easy-flowing, 
$257 \quad 10<$ FF: free-flowing.

\section{$258 \quad 2.6$. Statistical analysis}

259 All analyses were carried out in triplicates and reported values were means \pm standard 260 deviations. Statistical analysis was performed using the DSAASTAT add-on for Excel 2010 261 (Microsoft, Redmond, USA). The presence of significant differences between sample results 262 was investigated by one-way ANOVA and the means were separated by Tukey's HSD test at $p$ $263 \leq 0.05$. Pearson's correlation coefficients (r) were calculated to evaluate the degree of 264 correlation between investigated powder physicochemical and functional properties.

\section{3. RESULTS AND DISCUSSION}

266 3.1. Proximate composition of dromedary and cow's skim milks and milk powders

The proximate composition of spray-dried powders is displayed in Table 2. The total 269 solids, as well as fat, ash, and carbohydrate contents were significantly different between 270 produced powders. Moisture contents ranged between 2.98 and $7.04 \%(\mathrm{w} / \mathrm{w})$ on wet basis for 271 skim dromedary milk powders and between 3.37 and $5.56 \%(\mathrm{w} / \mathrm{w})$ on wet basis for skim cow's 272 milk powders. Generally, moisture content lower than $10 \%(\mathrm{w} / \mathrm{w})$ ensures powder stability 273 during storage (Kaur, Kaushal, \& Sandhu, 2011). When increasing the air outlet temperature 274 during spray-drying of both milk powders, the moisture content significantly decreased 275 whatever the milk type (cf. Table 2). This could be explained by the higher rate of evaporated 276 water and the lower feed rate in $\mathrm{C} 2$ conditions $\left(85^{\circ} \mathrm{C}\right.$ air outlet temperature and $65 \mathrm{~mL} \cdot \mathrm{min}^{-1}$ 277 feed flow-rate) compared to $\mathrm{C} 1$ conditions $\left(75^{\circ} \mathrm{C}\right.$ air outlet temperature and $75 \mathrm{~mL} \cdot \mathrm{min}^{-1}$ feed 278 flow-rate). The protein content of the dromedary and cow's milk powders did not exhibit any 279 significant difference. As the outlet air temperature was increased from 75 to $85{ }^{\circ} \mathrm{C}$, the 280 carbohydrates content increased from 53.74 to $55.66 \%(\mathrm{w} / \mathrm{w})$ on dry basis for skim dromedary 281 milk powder, while it decreased from 51.31 to $50.71 \%(\mathrm{w} / \mathrm{w})$ on dry basis for skim cow's milk 
282 powder. Also, upon air outlet temperature increase, the ash content decreased from 10.74 to $2838.90 \%(\mathrm{w} / \mathrm{w})$ on dry basis for dromedary milk powders and from 6.63 to $6.41 \%(\mathrm{w} / \mathrm{w})$ on dry 284 basis for cow's milk powders. This reduction of ash content could result from calcium phosphate 285 precipitation during the manufacture of skim milk powder (Lin, Kelly, O'Mahony, \& Guinee, 286 2018). Fat contents ranged between 12 and $16 \%(\mathrm{w} / \mathrm{w})$ on dry basis for skim dromedary and 287 cow's milk powders, respectively. These rather high fat contents ( $>2 \%$ on dry basis) suggested 288 that studied powders should be considered as partially skim milk powders. These results could 289 be justified by the fact that the conditions used for milk skimming by centrifugation in this 290 study were soft compared to what is commonly realized in the literature using a cream separator 291 (Heymann, 2016). Spray-drying conditions did not have a significant impact on the proximate 292 composition of studied milk powders. As it can be seen from Table 2, the proximate 293 compositions of skim milk powders were comparable to those of their corresponding milks.

294 Table 2 shows the water activity values of partially skim dromedary and cow's spray295 dried milks. Water activity was significantly influenced by spray-drying conditions whatever 296 the milk type: it was lower when milks were spray-dried in $\mathrm{C} 2$ conditions at $85{ }^{\circ} \mathrm{C}$ air outlet 297 temperature (0.203 and 0.274 for partially skim dromedary and cow's milk powders, 298 respectively) than in $\mathrm{C} 1$ conditions at $75^{\circ} \mathrm{C}$ air outlet temperature $(0.391$ and 0.385 for partially 299 skim dromedary and cow's milk powders, respectively). These results agreed with Zouari et al. 300 (2019) who reported that water activity of skim dromedary milk powder was lower when spray301 dried at $200{ }^{\circ} \mathrm{C}$ inlet air temperature compared to 160 and $180{ }^{\circ} \mathrm{C}$ air inlet temperatures. 302 Otherwise, Sulieman, Elamin, Elkhalifa, and Laleye (2014) showed that the concentration, 303 temperature, direction of the feed, and milk type did not affect water activity of dromedary milk 304 powders spray-dried at $200-220^{\circ} \mathrm{C}$ air inlet temperature and $98-105^{\circ} \mathrm{C}$ air outlet temperature, 305 but it gave different results for cow's milk powders spray-dried in the same conditions. Indeed, 
306 the ideal temperature range for spray-drying cow's milk are $175-240{ }^{\circ} \mathrm{C}$ for air inlet 307 temperature and $70-90{ }^{\circ} \mathrm{C}$ for air outlet temperature (Schuck, Jeantet, Dolivet, 2012).

\section{$308 \quad 3.2$. Particle size distribution of dromedary and cow's milk powders}

The granulometric characteristics of powders are shown in Table 3. All powders 310 exhibited monomodal particle size distributions centered around $14-20 \mu \mathrm{m}$ (Figure 1), 311 consistently with previous results obtained with the same combination of pilot spray-dryer and 312 bi-fluid nozzle (Guérin et al., 2017; Khanji et al., 2018). It should be mentioned that a significant 313 effect of both milk type and spray-drying conditions was observed on the particle size 314 distribution of spray-dried milk powders. The median particle sizes $\left(\mathrm{D}_{50}\right)$ as well as the particle 315 size distributions of spray-dried milk powders significantly differed according to spray-drying 316 conditions and milk type. As for the milk type, significantly higher median particle sizes $\left(\mathrm{D}_{50}\right)$ 317 were obtained for partially skim cow's milk powders whatever the spray-drying conditions. 318 This result could be explained by the difference in fat content between milk samples (Table 2): 319 indeed, partially skim cow's milk being richer in lipids, obtained powder was expected to be 320 stickier and then have a higher tendency to form agglomerates, leading to increased median 321 particle size. This hypothesis was confirmed by the significantly higher fines proportion of 322 partially skim cow's milk powders whatever the spray-drying conditions. As regards the 323 influence of spray-drying conditions, when increasing the air outlet temperature, median 324 particle size of partially skim dromedary and cow's milk powder was significantly higher but 325 no significant effect was observed for partially skim dromedary milk powders (Table 3). The 326 results obtained for skim cow's milk powders could be attributed to the fact that a higher drying 327 temperature and a lower feed-rate accelerates the drying rate of droplets, promoting the fast 328 formation of a crust at their surface and therefore limit shrinkage, which leads to larger particles 329 (Kim, Chen, \& Pearce, 2002). The fact that the particle size distribution of skim dromedary 330 milk was unaffected by spray-drying conditions may be an indication that crust formation did 
not occur upon drying of sprayed droplets, presumably owing to the protein content and casein

332 proportions differing from cow's milk (Felfoul et al., 2017 ; Lajnaf et al., 2017). Moreover,

333 these results confirm that feed flow-rate may have a minor influence on particle size distribution

334 of spray-dried skim milk powders, as particle size distributions obtained in all spray-drying

335 conditions remained close.

336 The span was rather close for all spray-dried milk powders, which showed that milk

337 type or spray-drying conditions did not have a great influence on the range of obtained particle

338 sizes. However, there was no marked effect of either the milk type or the spray-drying 339 conditions on the span of spray-dried milk powders.

\section{$340 \quad 3.3$. Basic flowability energy, bulk density, and specific energy}

341 Mean BFE values obtained from the stability test are presented in Table 4. BFE is known

342 to be a key parameter that expresses powder flowability in low-stress environments (Freeman,

343 2007). It is generally observed that powders exhibiting low BFE values have good flow

344 properties and inversely, high BFE is often obtained for powders that poorly flow. The BFE of 345 partially skim dromedary and cow's milk powders ranged from 620 to $1018 \mathrm{~mJ}$. The air outlet 346 temperature during spray-drying as well as the milk type exhibited noticeable effects on BFE 347 values. On one hand, partially skim dromedary milk powders had significantly lower BFE 348 values than partially skim cow's milk powders, denoting a better flowability of the former. On 349 the other hand, BFE of partially skim cow's milk powders was about $900 \mathrm{~mJ}$ whatever the spray350 drying conditions, whereas BFE of partially skim dromedary milk powders was well higher in $351 \mathrm{C} 2$ conditions $(1018 \mathrm{~mJ})$ than in $\mathrm{C} 1$ conditions $(620 \mathrm{~mJ})$.

352 Besides, milk type had significant effects on the BD values of spray-dried milk powders, 353 contrarily to spray-drying temperature that showed no significant impact on BD. Whatever the 354 spray-drying conditions; partially skim dromedary milk powders had significantly higher BD 355 values than partially skim cow's milk powders, i.e. 0.31 vs. 0.24 g.mL $\mathrm{mL}^{-1}$, respectively (Table 4). 
These differences could be attributed to milk powder proximate composition, particle 357 size or shape (Jan, Ghoroi, \& Saxena, 2017). Indeed, higher contents in sticky material, mainly 358 lipids, were observed for partially skim cow's milk powders. The presence of surface lipids is 359 expected to make particles stickier, thus increasing powder cohesion and decreasing bulk 360 density. Overall, BFE and BD of spray-dried milk powders, and thus flowability in low stress 361 conditions, was essentially influenced by particle size along with fat content. Specific energy indicates how easily powders flow in an unconfined environment and it 363 gives a good indication of the level of powder cohesion (Freeman, Cooke, \& Schneider, 2009). 364 SE of partially skim dromedary and cow's milk powders ranged from 8.49 to $15.59 \mathrm{~mJ} / \mathrm{g}$, which 365 corresponds to moderate-to-high cohesion (Bharadwaj, Ketterhagen, \& Hancock, 2010). SE 366 values were significantly affected by spray-drying conditions and milk type, as shown in Table 367 4. As for milk type, significantly higher SE values, indicating a poorer flowability, were 368 obtained for partially skim cow's milk powders whatever the spray-drying conditions. As 369 regards the influence of spray-drying conditions, SE of partially skim dromedary's milk 370 powders significantly increased in $\mathrm{C} 2$ conditions, indicating poorer flow properties. On the 371 contrary, spray-drying conditions had no significant effect on the SE of partially skim cow's 372 milk powders, indicating that they did not affect the flowability of cow's milk powder. The 373 lower SE of partially skim dromedary's milk powder spray-dried in C1 conditions $(8.49 \mathrm{~mJ} / \mathrm{g})$ 374 could be explained by differences in surface composition (Felfoul et al., 2020). Surface 375 composition of powder particles plays an important role in its flow behavior because flowability 376 involves overcoming surface interactions between powder particles (Fitzpatrick, Barringer, \& 377 Iqbal, 2004). Kim, Chen \& Pearce (2002) reported that a higher surface fat content might 378 explain the lower flow properties of industrial spray-dried milk powders. Thereby, studied 379 partially skim cow's milk powders, having significantly higher fat contents than partially skim 380 dromedary milk powders, had poorer flow powders whatever the spray-drying conditions. 
Based results obtained from the stability test (BD, BFE, and SE), the flow behavior of

382

383

384

385

386

387 388

389

390

391

392 the The milk type had noticeable effects on powder compressibility at $15 \mathrm{kPa}$, as displayed by

393 Table 4. In addition, the The higher the air outlet temperature applied during spray-drying of 394 dromedary milk, the higher the compressibility at $15 \mathrm{kPa}$ normal stress. On the contrary, for 395 For partially skim cow's milk powders, no significant difference of compressibility and CBD 396 could be attributed to spray-drying conditions. Moreover, partially skim dromedary milk 397 powders were less compressible than partially skim cow's milk powder whatever the spray398 drying conditions; this could be related to the better flow properties of partially skim dromedary 399 milk powder and to the higher fat content of partially skim cow's milk powder (Table 2). 400 Compressibility of studied milk powders increased in the following order: Dromedary_C1 < 401 Dromedary_C2 $<$ Cow_C1 $\approx$ Cow_C2, confirming the classification established on the basis 402 of BFE and SE values. Compressibility at $15 \mathrm{kPa}$ was significantly positively correlated to BFE 403 and SE (Pearson's correlation coefficients $r$ equaled 0.74 and 0.99 , respectively, cf. Table 5). Compressibility at $15 \mathrm{kPa}$ was also positively correlated to fat content (Pearson's 405 correlation coefficient $\mathrm{r}$ of 0.80 , cf. Table 5). Then, the higher the fat content, the more 
406 compressible the studied milk powder. Fat could act as lubricating agent at the surface of large 407 particle but not at the surface of small particles as reducing particle size increases the contact 408 area between particles allowing greater interaction between particles and thus higher cohesive 409 forces (Fitzpatrick, Barringer, \& Iqbal, 2004). In addition, fine particles exhibit higher 410 compressibility because of their greater specific surface area and the fewer interparticular voids 411 (Jan, Ghoroi, \& Saxena, 2017). Gnagne, Petit, Gaiani, Scher, \& Amani (2017) reported that 412 powders with a higher fine particle content and irregular morphology are likely to be more 413 susceptible to compression than more spherical, larger particles. These findings are in 414 disagreement with the results obtained in the present study, where it was observed that cow's 415 milk particles, of greater median size and having a higher fat content, were more compressible. 416 In the case of the present study, the usual negative impact of particle size on powder 417 compressibility is overcame by the high influence of fat content on powder cohesion, and thus 418 on its sensitivity to compression. However, it is worth noting that compressibility was positively 419 correlated with median particle size and BFE ( $\mathrm{r}=0.80$ and 0.74 , respectively, Table 5$)$. It has 420 been reported that particle size and milk powder composition, mainly fat content, were the key 421 factors influencing powder flowability. This confirms that the particle shape as well as the milk

422 powder composition, mainly fat content, are the main factors determining the flow behavior of 423 studied milk powders.

\section{$424 \quad 3.5$. Shear properties}

425 The yield locus of partially skim dromedary and cow's milk powders are presented in

426 Figure 3. Incipient shear stress logically increased with applied normal stress. Spray-drying 427 conditions and milk type significantly influenced the shear flow properties of spray-dried 428 powders (Table 4). Partially skim cow's milk powders were more cohesive (around $5 \mathrm{kPa}$ 429 cohesion) than partially skim dromedary milk powders (around $4 \mathrm{kPa}$ cohesion) whatever the 430 spray-drying conditions, indicating a poorer flowability of partially skim cow's milk powders, 
431 in agreement with previously evoked flow properties and the higher fat content of partially skim

432 cow's milk. No significant effect of the air outlet temperature was denoted on the cohesion and

433 FF values of the investigated powders. Similarly, no significant effect of the outlet air

434 temperature on the FF values was also observed, showing that both milk powders were

435 extremely cohesive regardless of the applied spray-drying conditions. According to Jenike's

436 elassification all produced powders came under the category of very cohesive materiat and thus

437 exhibited very poor flow properties. Shear and compressibility test results were in good

438 agreement, i.e. the higher the powder cohesion, the lower the FF values, the more compressible

439 the powder bed. Based on stability, compressibility, and shear tests, the flow behavior of all

440 studied powders could be sorted as follows, from poorer to better flowability: Cow_C1 $\approx$

441 Cow_C2 $<$ Dromedary_C2 $<$ Dromedary_C1. Possible reasons for this classification could be

442 the differences in milk composition (mainly fat content), particle size, particle interlocking,

443 packing of smaller particles in void spaces, and surface irregularity, enabling higher cohesive

444 interactions (Fitzpatrick, Barringer, \& Iqbal, 2004; Siliveru, Kwek, Lau, \& Ambrose, 2016;

445 Siliveru, Jange, Kwek, Ambrose, 2017; Jan, Ghoroi, \& Saxena, 2017). In the case of the present

446 study, fat content could justify observed differences in flowability, as it was higher for partially

447 skim cow's milk powder than for partially skim dromedary's milk powder (about 16 vs. $12 \%$

$448(\mathrm{w} / \mathrm{w})$ on dry basis, respectively, cf. Table 2). Significant correlations of cohesion and FF to fat

449 content (Pearson's correlation coefficients $r$ of 0.99 and 0.97 , respectively, cf. Table 5) were

450 obtained, indicating that the presence of fat was surely the main reason of flowability

451 impairment of studied powders. Significantly positive correlations of cohesion and FF to

452 particle size (Pearson's correlation coefficients $\mathrm{r}$ of 0.88 and 0.77 , respectively, cf. Table 5)

453 were also evidenced. This suggests that particle morphology (more specifically particle size

454 distribution) significantly impacted flowability of studied powders, consistently with Babu,

455 Siliveru, Amamcharla, Vadlani, and Ambrose (2018). Teunou, Fitzpatrick, and Synnott (1999) 
456 also studied the flowability of milk powders differing in particle size and composition (skim 457 milk and whey powders), concluding that the particle size significantly affects flowability: 458 smaller particles possess more contact points with the neighboring particles, thus making 459 rearrangements of the powder bed more difficult and impairing its flowability. The poor 460 flowability of milk powders was also probably due to their irregular surface particles, leading 461 to increased interparticular interactions and particle interlocking (Hart, 2015). Similar 462 observations were reported for different pharmaceutical powders by Lindberg et al. (2004).

\section{4. CONCLUSION}

464 The spray-drying process has a significant impact on milk powder flow properties. In 465 this study, partially skim dromedary and cow's milks were spray-dried in different conditions 466 (of air outlet temperature and feed flow-rate) without prior concentration to avoid introducing 467 another source of process variability. Partially skim dromedary and cow's milk powders were 468 very cohesive. The spray-drying conditions, the milk type, the particle size distribution as well 469 as the residual fat content showed a great influence on flow properties of partially skim 470 dromedary and cow's milk powders. Using a higher air outlet temperature $\left(85^{\circ} \mathrm{C}\right)$ led to poorer

471 flowability and higher compressibility whatever the milk type. Shear tests showed that partially 472 skim cow's milk powders were more cohesive than partially skim dromedary milk powders.

473 The shear flow properties of milk powders are expected to be influenced by fat content, particle 474 size distribution, particle morphology, particle interlocking, packing of smaller particles in void 475 spaces, and surface irregularity. Furthermore, in order to help industrializing dromedary milk 476 powder production, further investigations should focus on biochemical and technological 477 (gelation, coagulation, etc.) properties of dromedary milk powders.

\section{CONFLICT OF INTEREST}

479 The authors declare no conflict of interest. 
480

481

482 Scientific Research of Tunisia through the scholarship program under the project called 483 Mobility to Encourage Young Tunisian Researchers ( ${ }^{\circ}$ 18PJEC12-20, 2018). The authors 484 acknowledge also support of the LIBio by the "Impact Biomolecules" project of the "Lorraine 485 Université d'Excellence" (Investissements d'avenir - ANR). The authors would also like to 486 thank all the LIBio members for their help and support as well as Alexandre Laflotte from the 487 experimental domain of La Bouzule for cow's milk supply.

\section{ETHICAL STATEMENT}

489 This research study does not include animal and human testing.

490

\section{DATA AVAILABILITY STATEMENT}

491 We declare that the data that support the findings of this study are openly available for all useful 492 purposes.

\section{REFERENCES}

494 495 Rockville, Maryland, USA: AOAC international.

496 Al-Juboori, A. T., Mohammed, M., Rashid, J., Kurian, J., \& El Refaey, S. (2013). 497 Nutritional and medicinal value of camel (Camelus dromedarius) milk. Food and Environment 498 Ii: The Quest for a Sustainable Future, 170, 221-232.

499 ASTM (2004). One-Dimensional Consolidation Properties of Soils Using Incremental 500 Loading.

501 ASTM D2435-04, West Conshohocken, PA. ASTM (2005). Standard test method for 502 unconfined compressive strength of cohesive soil. D2166, West Conshohocken, PA. 

504 (2018). Influence of protein content and storage temperature on the particle morphology and 505 flowability characteristics of milk protein concentrate powders. Journal of Dairy Science, 101, 506 1-14.

Bharadwaj, R., Ketterhagen, W. R., \& Hancock, B. C. (2010). Discrete element 508 simulation study of a Freeman powder rheometer. Chemical Engineering Science, 65, 57475095756.

Bian, Q., Ambrose, R. P. K., \& Subramanyam, Bh. (2015). Effect of chaff on bulk flow 511 properties of wheat. Journal of Stored Products Research, 64, 21-26.

513 parameters of freeze-dried soursop fruit pulp. Journal of Food Engineering, 111, 360-365.

514 Esquivel, P., \& Jiménez, V. M. (2012). Functional properties of coffee and coffee by515 products. Food Research International, 46, 488-495.

516 Felfoul, I., Jardin, J., Gaucheron, F., Attia, H., \& Ayadi, M. A. (2017). Proteomic 517 profiling of camel and cow milk proteins under heat treatment. Food Chemistry, 216, 161-169. 518 Felfoul, I., Burgain, J., Perroud, C., Gaiani, C., Scher, J., Attia, H., \& Petit, 519 J. (2020). Impact of spray-drying conditions on physicochemical properties and rehydration 520 ability of skim dromedary and cow's milk powders, Drying 521 Technology. DOI: $\underline{\text { 10.1080/07373937.2020.1828448 }}$

522 Fitzpatrick, J. J., Barringer, S. A., \& Iqbal, T. (2004). Flow property measurement of 523 food powders and sensitivity of Jenike's hopper design methodology to the measured values. 524 Journal of Food Engineering, 61, 399- 405.

525 Fitzpatrick, J. J., Barry, K., Cerqueira, P. S. M., Iqbal, T., O’Neill, J., \& Roos, Y. H. 526 (2007). Effect of composition and storage conditions on the flowability of dairy powders. 527 International Dairy Journal, 17, 383-392. 
Folch, J., Lees, M., \& Sioane-Staniey, G. A. (1957). A simple method for isolation and

529 purification of total lipids from animal tissues. Journal of Biological Chemistry, 266, 497 - 509.

531 aerated powders - a comparative study using a powder rheometer and a rotational shear cell.

532 Powder Technology, 174, 25-33.

533 Freeman, R. E., Cooke, J. R., \& Schneider, L. C. R. (2009). Measuring shear properties 534 and normal stresses generated within a rotational shear cell for consolidated and non535 consolidated powders. Powder Technology, 190, 65-69.

536 Freeman, R., \& Fu, X. (2008). Characterisation of powder bulk, dynamic flow and shear 537 properties in relation to die filling. Powder Metallurgy, 51, 196-201.

538 Freeman, T. (2011). Characterizing Powder Flow. Chemical Engineering Journal, 118, $53966-72$.

540 Gaiani, C., Morand, M., Sanchez, C., Tehrany, E. A., Jacquot, M., \& Schuck, P. (2010).

541 How surface composition of high milk proteins powders is influenced by spray-drying 542 temperature. Colloids and Surfaces B: Biointerfaces, 75, 377-384.

543 Gnagne, E. H., Petit, J., Gaiani, C., Scher, J., \& Amani, G. N. (2017). Characterisation 544 of flow properties of foutou and foufou flours, staple foods in West Africa, using the FT4 545 powder rheometer. Journal of Food Measurement and Characterization, 11, 1128-1136.

546 Guerin, J., Petit, J., Burgain, J., Borges, F., Bhandari, B., Perroud, C., Desobry, S., 547 Scher, J., \& Gaiani, C. (2017). Lactobacillus rhamnosus GG encapsulation by spray-drying : 548 Milk proteins clotting control to produce innovative matrices. Journal of Food Engineering, $549193,10-19$.

550 Hammes, M. V., Englert, A. H., Noreña, C. P. Z., \& Cardozo, N. S. M. (2015). Study 551 of the influence of soy lecithin addition on the wettability of Buffalo milk powder obtained by 552 spray-drying. Powder Technology, 277, 237-243. 
Hart, A. (2015). Effect of Particle Size on Detergent Powders Flowability and 554 Tabletability. Journal of Chemical Engineering and Process Technology, 6, 215.

556 Changes in physicochemical properties of spray-dried camel milk powder over accelerated 557 storage. Food Chemistry, 295, 224-233.

558 Jan, S., Ghoroi, C., \& Saxena, D. C. (2017). Characterisation of bulk and shear 559 properties of basmati and non-basmati rice flour in relation to flowability. Journal of Cereal 560 Science, 76, 215-221.

561 Jenike, A. W. (1964). Storage and flow of solids, Bull. No. 123. Utah Engineering. 562 Station, Univ. Utah, Salt Lake City.

563 Jenike, A. W. (1980). Storage and flow of solids. Bull. No, 123, 20 ${ }^{\text {th }}$ Printing, revised. 564 Engng. Exp. Station, Univ. of Utah, Salt Lake City (1964/1980).

565 Jinapong, N., Suphantharika, M., \& Jamnong, P. (2008). Production of instant soymilk 566 powders by ultrafiltration, spray drying and fluidized bed agglomeration. Journal of Food 567 Engineering, 84, 194-205.

568 Kaur, M., Kaushal, P., \& Sandhu, S. K. (2011). Studies on physicochemical and pasting 569 properties of Taro (Colocasia esculenta L.) flour in comparison with a cereal, tuber and legume 570 flour. Journal of Food Science and Technology, 50, 94-100.

571 Khanji, A. N., Michaux, F., Petit, J., Salameh, D., Rizk, T., Jasniewski, J., \& Banon, S. 572 (2018). Structure, gelation, and antioxidant properties of curcumin-doped casein micelle 573 powder produced by spray-drying. Food and Function, 9, 971 - 981.

574 Kim, E. H. J., Chen, X. D., \& Pearce, D. (2002). Surface characterization of four 575 industrial spray-dried powders in relation to chemical composition, structure and wetting 576 property. Colloids and Surfaces B: Biointerfaces, 26, 197-212. 
Kitamura, Y., Itoh, H., \& Echizen, H. (2009). Experimental vacuum spray drying of 578 probiotic foods, included with lactic acid bacteria. Journal of Food Processing and 579 Preservation, 33, 714-726.

580 Krantz, M., Zhang, H., \& Zhu, J. (2009). Characterization of powder flow: Static and 581 dynamic testing. Powder Technology, 4, 239-245.

582 Lajnaf, R., Picart-Palmade, L., Attia, H., Marchesseau, S., \& Ayadi, M. A. (2017).

583 Foaming and adsorption behavior of bovine and camel proteins mixed layers at the air/water 584 interface. Colloids and Surfaces B: Biointerfaces, 151, 287-294.

585 Lapčík, L., Lapčíková, B., Otyepková, E., Otyepka, M., Vlček, J., Buňka, F., \& Salek, 586 R. N. (2015). Surface energy analysis (SEA) and rheology of powder milk dairy products. Food 587 Chemistry, 174, 25-30.

588 Lin, Y., Kelly, A. L., O'Mahony, J.A ., \& Guinee, T. P. (2018). Effect of heat treatment, 589 evaporation and spray drying during skim milk powder manufacture on the compositional and 590 processing characteristics of reconstituted skim milk and concentrate. International Dairy 591 Journal, 78, 53-64.

592 Lindberg, N. O., Pålsson, M., Pihl, A. C., Freeman, R., Freeman, T., Zetzener, H., \& 593 Enstad, G. (2004). Flowability measurements of pharmaceutical powder mixtures with poor 594 flow using five different techniques. Drug Development and Industrial Pharmacy, 30, 785-791. 595 Lu, H., Guo, X., Jin, Y., \& Gong, X. (2018). Effect of moisture on flowability of 596 pulverized 503 coal. Chemical Engineering Research and Design, 133, 326-334.

597 Mandato, S., Rondet, E., Delaplace, G., Brkouti, A., Accart, P., Ruiz, T., Cuq, B. (2012).

598 Liquids atomization with two different nozzles: modelling of the effects of some processing 599 and formulation conditions by dimensional analysis. Powder Technology, 224, 323-330. 
601 Battula, S. N. (2017). Influence of moisture content on the flow properties of basundi mix. 602 Powder Technology, 312, 133-143.

Petit, J., Méjean, S., Accart, P., Galet, L., Schuck, P., Le Floch-Fouéré, C., Delaplace, 604 G., \& Jeantet, R. (2015). A dimensional analysis approach for modelling the size of droplets 605 formed by bi-fluid atomisation. Journal of Food Engineering, 149, 237-247.

606 Quintanilla, M. A. S., Castellanos, A., \& Valverde, J. M. (2001). Correlation between 607 bulk stresses and interparticle contact forces in fine powders. Physical Review E Statistical 608 Nonlinear Soft Matter Physics, 64, 51-54.

609 Reddy, R. S., Ramachandra, C. T., Hiregoudar, S., Nidoni, U., Ram, J., \& Kammar, M. 610 (2014). Influence of processing conditions on functional and reconstitution properties of milk 611 powder made from Osmanabadi goat milk by spray drying. Small Ruminant Research, 119, $612130-137$.

613 Salameh, C., Scher, J., Petit, J., Gaiani, C., Hosri, C., \& Banon, S. (2016). Physico614 chemical and rheological properties of Lebanese kishk powder, a dried fermented milk-cereal 615 mixture. Powder Technology, 292, 307-313.

616 Schuck, P., Jeantet, R., \& Dolivet, A. (2012). Analytical Methods for Food and Dairy 617 Powders; John Wiley \& Sons: Oxford.

618 Siliveru, K., Jange, C. J., Kwek, J. W., \& Ambrose, R. P. K. (2017). Granular bond 619 number model to predict the flow of fine flour powders using particle properties. Journal of 620 Food Engineering, 208, 11-18.

621 Siliveru, K., Kwek, J. W., Lau, G. M., \& Ambrose, R. P. K. (2016). An image analysis 622 approach to understand the differences in flour particle surface and shape characteristics. Cereal 623 Chemistry, 93, 234-241. 
624 Sulieman, A. M. E., Elamin, O. M., Elkhalifa, E. A., \& Laleye, L. (2014). Comparison 625 of physicochemical properties of spray-dried camel's milk and cow's milk powder. 626 International Journal of Food Science and Nutrition Engineering, 4, 15-19.

627 Teunou, E., Fitzpatrick, J. J., \& Synnott, E. C. (1999). Characterisation of food powder 628 flowability. Journal of Food Engineering, 39, 31-37.

629 Zouari, A., Perrone, I. T., Schuck, P., Gaucheron, F., Dolivet, A., Attia, H., \& Ayadi, 630 M.A. (2019). Effect of outlet drying temperature and milk fat content on the physicochemical 631 characteristics of spray-dried camel milk powder. Drying Technology, 37, 1615-1624. 


\section{Figure captions}

633 Fig. 1. Particle size distributions of skim dromedary and cow's milk powders spray-dried at 75 $634(\mathrm{C} 1)$ and $85^{\circ} \mathrm{C}(\mathrm{C} 2)$ air outlet temperatures.

635 Fig. 2. Compressibility of partially skim dromedary and cow's milk powders. Error bars 636 represent standard deviations.

637 Fig. 3. Evolution of shear stress with applied normal stress for partially skim dromedary and 638 cow's milk powders. Error bars correspond to standard deviations. 


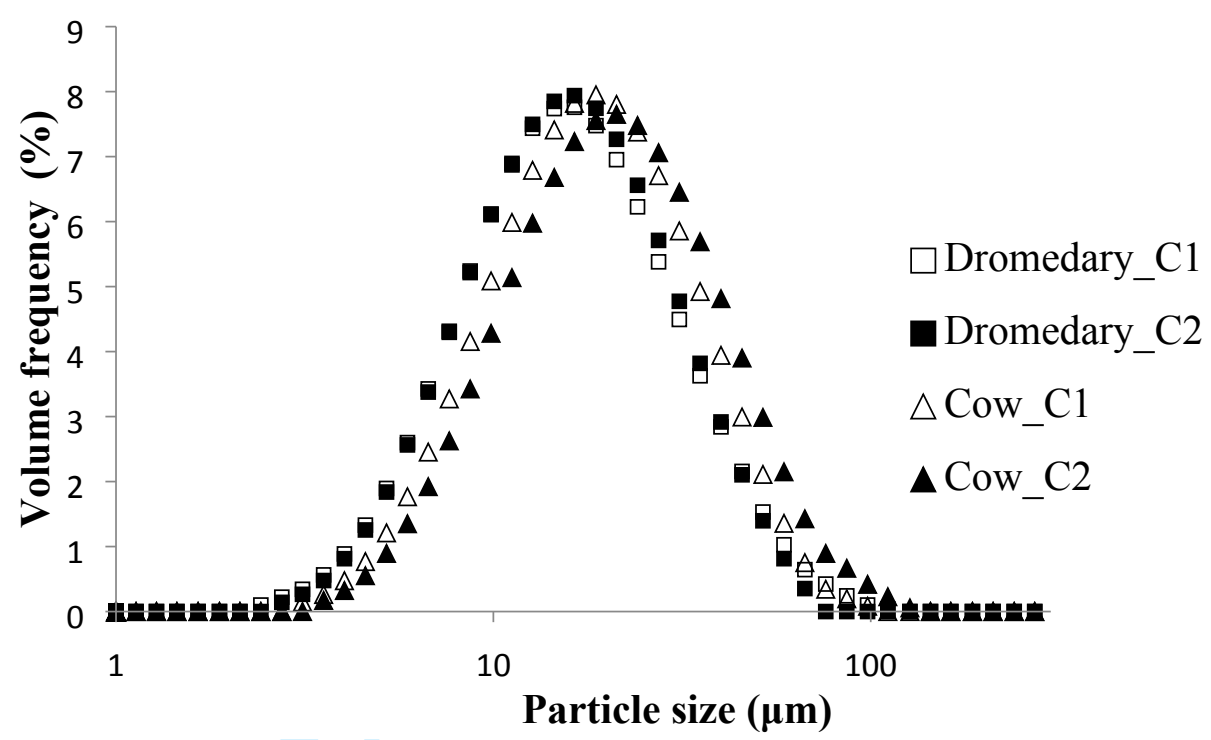

Fig. 1. 


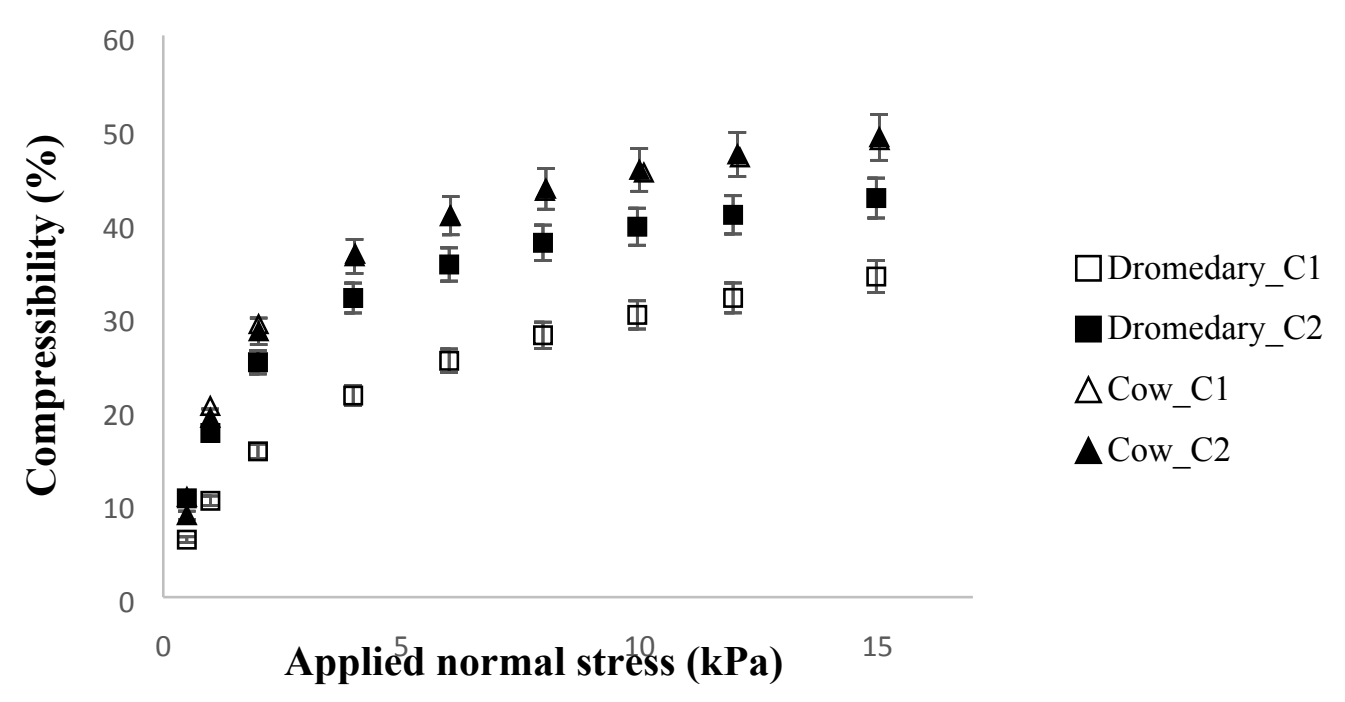

Fig. 2. 


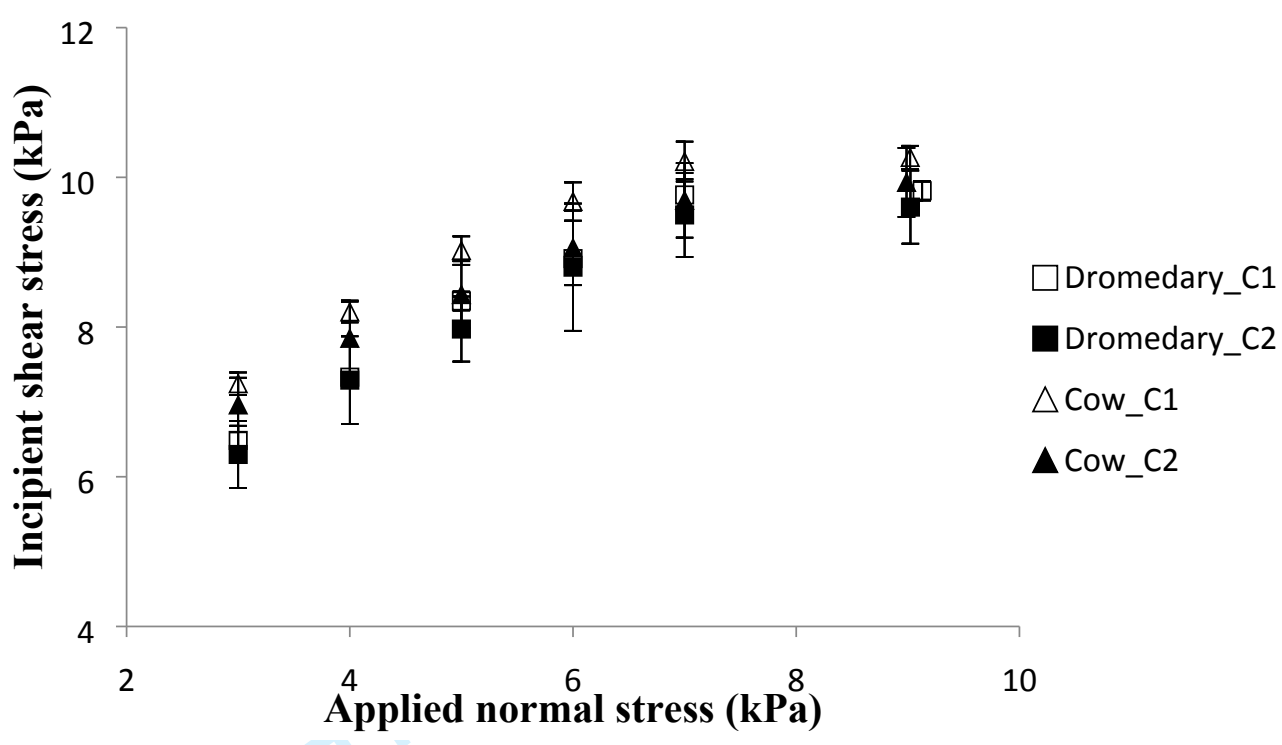

Fig. 3. 
Table 1. Spray-drying conditions used for the production of skim dromedary and cow's milk powders.

\begin{tabular}{cccccc}
\hline Skim milk & Powder sample & Spray-drying & Air inlet & Air outlet & Feed flow \\
sample & acronym & conditions & temperature & temperature & rate \\
& & & $\left({ }^{\circ} \mathrm{C}\right)$ & $\left({ }^{\circ} \mathrm{C}\right)$ & $\left(\mathrm{mL}^{\left.-\mathrm{min}^{-1}\right)}\right.$ \\
\hline Dromedary & Dromedary_C1 & $\mathrm{C} 1$ & $230.0+/-1.3$ & $74.5+/-0.7$ & $74.7+/-2.1$ \\
Cow & Cow_C1 & $\mathrm{C} 1$ & $230.4+/-1.6$ & $74.4+/-0.9$ & $76.5+/-2.2$ \\
Dromedary & Dromedary_C2 & $\mathrm{C} 2$ & $230.3+/-1.8$ & $84.3+/-1.1$ & $65.4+/-3.7$ \\
Cow & Cow_C2 & $\mathrm{C} 2$ & $230.6+/-1.3$ & $84.8+/-0.8$ & $69.5+/-2.9$ \\
& & & & & \\
\hline
\end{tabular}


Table 2. Proximate composition of dromedary and cow's skim milks and powders produced in the two spray-drying assays.

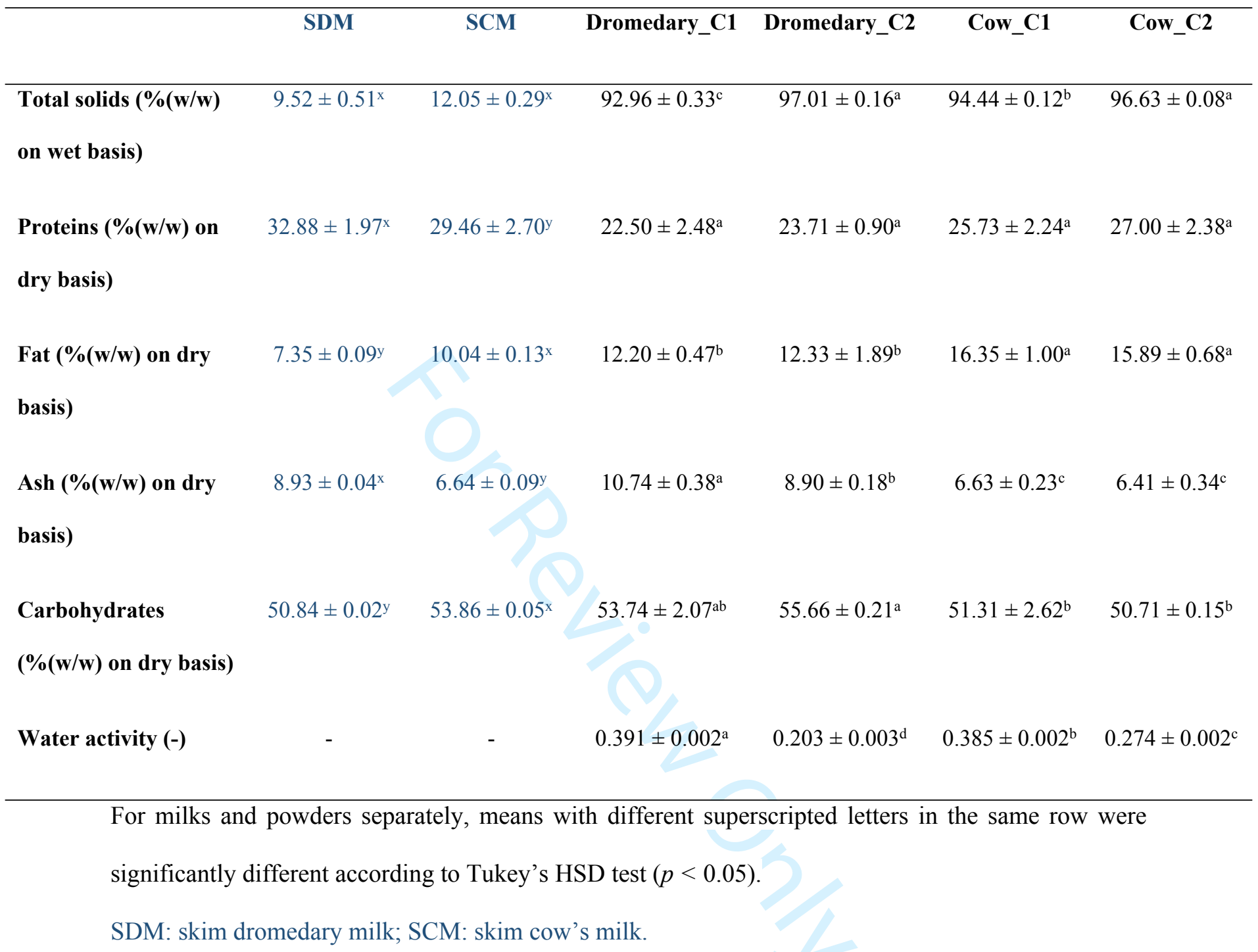


Table 3. Granulometric characteristics of skim dromedary and cow's milk powders.

\begin{tabular}{lcccc}
\hline & Dromedary_C1 & Dromedary_C2 & Cow_C1 & Cow_C2 \\
\hline $\mathbf{D}_{\mathbf{1 0}}(\boldsymbol{\mu \mathbf { m } )}$ & $6.41 \pm 0.06^{\mathrm{d}}$ & $6.55 \pm 0.10^{\mathrm{c}}$ & $7.54 \pm 0.06^{\mathrm{b}}$ & $8.28 \pm 0.03^{\mathrm{a}}$ \\
$\mathbf{D}_{\mathbf{5 0}}(\boldsymbol{\mu \mathbf { m }})$ & $14.83 \pm 0.08^{\mathrm{c}}$ & $14.84 \pm 0.21^{\mathrm{c}}$ & $17.09 \pm 0.18^{\mathrm{b}}$ & $19.19 \pm 0.10^{\mathrm{a}}$ \\
$\mathbf{D}_{\mathbf{9 0}}(\boldsymbol{\mu m})$ & $35.09 \pm 0.36^{\mathrm{c}}$ & $32.68 \pm 0.34^{\mathrm{d}}$ & $37.43 \pm 0.50^{\mathrm{b}}$ & $43.04 \pm 0.33^{\mathrm{a}}$ \\
& & & & \\
Span (-) & $1.93 \pm 0.02^{\mathrm{a}}$ & $1.76 \pm 0.01^{\mathrm{c}}$ & $1.75 \pm 0.01^{\mathrm{c}}$ & $1.81 \pm 0.01^{\mathrm{b}}$ \\
\hline & & & \\
\hline & &
\end{tabular}


Table 4. Flow properties issued from stability, compressibility, and shear cell tests of skim dromedary and cow's milk powders deduced from the FT4 stability test.

\section{Dromedary_C1 Dromedary_C2 Cow_C1 Cow_C2}

\begin{tabular}{|c|c|c|c|c|}
\hline BFE (mJ) & $620 \pm 27^{b}$ & $1018 \pm 65^{\mathrm{a}}$ & $917 \pm 81^{\mathrm{a}}$ & $907 \pm 68^{a}$ \\
\hline SE (mJ.g $\left.g^{-1}\right)$ & $8.49 \pm 0.46^{\mathrm{c}}$ & $12.73 \pm 0.12^{b}$ & $15.52 \pm 0.14^{\mathrm{a}}$ & $15.59 \pm 0.30^{\mathrm{a}}$ \\
\hline BD $\left(g \cdot m L^{-1}\right)$ & $0.31 \pm 0.00^{\mathrm{a}}$ & $0.31 \pm 0.00^{\mathrm{b}}$ & $0.24 \pm 0.00^{\mathrm{d}}$ & $0.25 \pm 0.00^{\mathrm{c}}$ \\
\hline $\begin{array}{c}\text { CBD at } 15 \mathrm{kPa} \\
\left(\mathrm{g} \cdot \mathrm{mL}^{-1}\right)\end{array}$ & $0.47 \pm 0.00^{b}$ & $0.53 \pm 0.00^{\mathrm{a}}$ & $0.48 \pm 0.01^{\mathrm{b}}$ & $0.49 \pm 0.01^{\mathrm{b}}$ \\
\hline $\begin{array}{l}\text { Compressibility at } \\
\qquad 15 \mathrm{kPa}(\%)\end{array}$ & $34.2 \pm 1.1^{\mathrm{c}}$ & $42.6 \pm 0.7^{b}$ & $48.8 \pm 1.2^{\mathrm{a}}$ & $49.1 \pm 1.2^{\mathrm{a}}$ \\
\hline Cohesion (kPa) & $4.07 \pm 0.13^{b}$ & $4.01 \pm 0.35^{b}$ & $5.16 \pm 0.05^{\mathrm{a}}$ & $5.06 \pm 0.36^{\mathrm{a}}$ \\
\hline FF (-) & $1.21 \pm 0.04^{\mathrm{a}}$ & $1.24 \pm 0.11^{\mathrm{a}}$ & $1.02 \pm 0.02^{\mathrm{b}}$ & $1.09 \pm 0.06^{\mathrm{ab}}$ \\
\hline
\end{tabular}


Table 5. Pearson's correlation coefficients between flow and physicochemical properties.

4

5

6

7

8

9

10

11 Compressibility at 15

12

13

14

15

Cohesion (kPa)

0.85

Cohesion

FF (-)

BFE (mJ)

SE (mJ.g-1)

Fat content

$\mathrm{D}_{50}(\mu \mathrm{m})$

at $15 \mathrm{kPa}(\%) \quad(\mathrm{kPa})$

$(\%(w / w)$ on

dry basis)

16

17

18

19

20

21

22

23 Fat content $(\%(w / w)$

24

25

26

27

28

29

30

31

32

33

34

35

36

37

38

39

40

41

42

43

44

45

46

47

48

49

50

51

52

53

54

55

56

57

58

59

60

0.85

$\begin{array}{ll}- & -0.97\end{array}$

$-0.97$

0.28

0.83

0.99

0.88

$-0.76$

0.28

0.78

0.87 